\title{
The Debate on the Meaning of Literature in Italy Today
}

Lucia $\operatorname{Re}$

The need to assess the fate of the avantgarde, the wish to make some sense of the most recent developments on the literary scene, and the effort to rethink the function of literary research and writing, have recently generated a series of interesting critical exchanges in Italy. Under the auspices of the journals Alfabeta (Milan), and Acquario (Palermo), a symposium on "the meaning of literature" was held in Palermo in November 1984. The symposium (which included readings of unpublished literary texts) brought together some of the most important writers and critics active in Italy today to discuss the issues raised on the pages of Alfabeta and various other journals and newspapers in the context of what appears to be a renewed collective urge for clarification opposed to the atmosphere of intellectual dispersion and confusion of the 1970s and 1980s.

Ex-members of the neo-Avanguardia, the Novissimi and the Gruppo 63, such as Sanguineti, Anceschi, Leonetti, Pagliarani, Porta, and Angelo Guglielmi took part in the debate, along with representatives of several different generations, creative orientations, and critical tendencies, such as Stefano Agosti, Gian Carlo Ferretti, Giovanni Raboni, Enzo Cucchi, and Biancamaria Frabotta. What prompted all these people to intervene directly or indirectly in the debate, and to participate in the Palermo symposium? Many participants expressed a feeling of "affectionate nostalgia" caused by the near-coincidence of this gathering with the twentieth anniversary of the Gruppo 63. Some of the most ardent opponents of the group, such as De Marco and Fortini, hoped on the other hand this would be the occasion for the group's "final and definitive entombment." The Gattopardo-like, "voluptuous immobility" of Palermo, and the setting of the symposium in the very same Hotel delle Palme where the first historic 
meeting of the Gruppo 63 had taken place, contributed to create a sense of déjà vu. But this symposium was intended neither as a celebration nor as a funerary ritual. Two main motivations emerged. First of all, the need, expressly stated by Barilli and Porta, to find once again a place and an opportunity for dialogue in order to overcome the widespread sense of isolation and fragmentation felt by writers and critics in recent years. The lively response to the symposium's theme list published in Alfabeta (no 62/63, July/Aug. 1984) is also indicative of a new propensity towards the rationalization of literary discourse, and of the need to situate literature once again in a specific historical and ideological network in order to define its function as a cultural force. Almost all contributors to the debate before, during, and after the symposium, expressed a renewed concern for the "status of literary work" in the context of the problems of the publishing industry and of "media hegemony," as well as in conjunction with the new technologies and the "pseudo-" or "para-" literature of today's consumer society. While no conclusions or programs were agreed upon, the texts read at the symposium and the debate which followed constitute an eloquent document of the directions aesthetic research is taking in Italy today. Twenty years later, the problems posed by the complex theoretical debates of the 60 s and by the experiments of the Avanguardia seem still quite relevant, and - although perspectives and practices have in many ways radically changed - the self-reflectiveness and the political awareness which prompted the first meeting of the Gruppo 63 appear to have become once again prominent features in the Italian cultural scene.

The absences, the silences, and the reticence of some were statements in themselves, and proved to be vital contributions to the debate. The involuntary absence of Nanni Balestrini, detained in France, dramatically reminded those present of the indivisibility of literary and political discourse. Giuliani, also absent, confirmed his belief in the validity of certain strategies of desecration advocated by the neo-Avanguardia. From the pages of Rinascita, he upheld "the choice of parody, of an ironic and awkward attitude, with which the author can and must look at himself" ("Fare poesia dopo i Novissimi" [Writing Poetry after the "Novissimi"], interview edited by F. Bettini, June 24, 1984). He then claimed that "the Gruppo 63 never existed" ("Non è mai esistito," La Repubblica October 9, 1984). Calvino, whose Palomar was among the most quoted texts at the meeting, along with texts by Jabès 
and Perec, did not contribute directly, but suggested implicitly that the proposal to clarify "the directions of work in the currents, in the journals, in the operative modes" was equivalent to tracing the map of an invisible city. According to Calvino in fact, the "Gruppo 63" remains "the last attempt to chart a general map of literature" ("Gli ultimi fuochi" [The Last Fires], in La Repubblica, October 9, 1984). Another absent but often-mentioned protagonist of the Italian literary scene was Umberto Eco, busy lecturing "in American universities."

The oral presentations, the readings of unpublished literary texts, and the public debate (attended by a very young and attentive audience, mostly made up of students), confirmed the emergence of two contrasting lines of interest that had already surfaced in the written contributions published before the meeting. The first line, mostly of Marxist orientation, is concerned with ethical and political problems which were already present in at least one wing of the neo-Avanguardia (Leonetti, Pagliarani, Sanguineti). This line comprises two secondary tendencies, one stressing the role of History, and the other the role of Life in the shaping of literary discourse. Both take a polemical stand against the notions of self-referentiality and intertextuality in literature. The second line, less polemical and with fewer supporters than the first, is linked to post-Nietzschean and post-Heideggerian thought, to the critique of the subject, and to the problematics of deconstruction and "weak ontology." For this second line, the problem of the "meaning of literature" is either a "false problem," or one that requires a paradoxical response (the meaning of literature is non-sense), or the problematical posing of the problem itself (what does "meaning" mean?).

Three principal themes were touched on in practically all the contributions, a fact that confirms the extraordinary communality of interests despite the difference in approach between the two lines. The "loss of certainties" as an epistemological problem that concerns not only literary discourse, but the existential and political realms as well, was repeatedly alluded to, often in conjunction with a second theme of common interest: the effect of new technologies and mass media on the production and reception of literature. Finally, all contributors referred to the notion of the "post-modern" and to its function as the creative and critical discourse of our time. 
Leonetti (co-editor of the journal Alfabeta along with Nanni Balestrini, Omar Calabrese, Maria Corti, Gino di Maggio, Umberto Eco, Antonio Porta, Pier Aldo Rovatti, Gianni Sassi, Mario Spinella and Paolo Volponi) opened the debate from the pages of Alfabeta, declaring himself "critically concerned about the loss of certainty prevalent in literary and artistic works, not merely because today we are skeptical of the notion of episteme in scientific endeavors, but because we doubt it as a result of the collapse of social and political activitism of the last twenty years." ("Stile e statuto (ieri, oggi)" [Style and Statute (Yesterday, Today], Alfabeta 57, February 1983). Leonetti links this loss of certainty to the editorial situation and to the new technologies which overdetermine individual choices to the point of immediately rendering "dated every oppositional operation of the simplest type." In order to renew the struggle for invention it is therefore necessary to work in the "interstices" ("it is also necessary to make one's way onto the news-stands, it is a matter of learning how to do it well") and to react against the hazard of the post-modern by means of a new semantization of literary discourse. This new semantization must be "plurivocal": Leonetti defines it as a "cross-eyed" or "two-faced expressionism" which looks both forward and backward, avoiding the risks of becoming a mannerism or a neoclassicism masquerading as post-modern or trans-Avanguardia.

This call for a new ethical-political-formal "engagement" of literary discourse was repeated by Anceschi in a text (read by Antonio Porta), entitled "Knowledge, Power, and Poetry." Sanguineti's remarks also supported this view (there are more poisons than pleasures in literature: the sabotage of literature is important today, the meaning of literature is in anti-literature, in the "battle against power"), as did the strongly polemical remarks made by Angelo Guglielmi, the ex-exponent of the neo-Avanguardia who seems to have changed his own position with respect to the $60 \mathrm{~s}$ more than anyone else.

Guglielmi launched a real attack against the "formalization of literature and criticism" in Italy. He defined it as a "mystification of reality," and argued polemically against skepticism and "the uncertainty" promoted by the post-modern movement (above all in the field of the visual arts, the Biennale of 1984, the transAvanguardia, etc.), understood as the sacking of the museum of the past, the construction of texts made up entirely of fragments and quotes without any real content or commitment. For 
Guglielmi, who cited Porta and Pontiggia as "positive examples," writing must be a poetic practice of "resistance," a struggle in the "inferno of language." In written remarks published earlier ("Una democrazia delle forme" [A Democracy of Forms], Alfabeta no. 59, April 1984, p. 6-7), Guglielmi outlines a surprisingly different notion of the post-modern, which is especially valuable because it demonstrates (as Umberto Eco has noted) how vacuous this term really is, and how it constitutes, all things considered, a polyvalent metaphor. According to Guglielmi, the post-modern, of which The Name of the Rose is supposed to be a typical example, represents the most positive meeting point for avant-garde literature and paraliterature, both of which were born, although with opposite objectives, "as a result of the new needs introduced by the society of the masses." This reflection on avant-garde literature and paraliterature as forms of democratic rebellion "against Art with a capital 'a'" leads Guglielmi to review his judgment of writers like Pasolini, the Morante of History: A Novel, and even Fruttero and Lucentini. In fact, these very writers found that "the true element of novelty that characterizes avant-garde literary research ... is a political practice rather than a literary strategy ... ., that is, a "new form of . . more democratic communication." A post-modern text such as The Name of the Rose, with its recovery of plot and of the "activity of story-telling to which not only the development of man but the survival of life itself is bound," combines "a maximum of formalization with a maximum of communicative capacity."

Marco Forti cites Eco's novel as well ("Esempi sintomatici" [Symptomatic Examples], Alfabeta no. 61, June 1984, p. 6-7), as an example of how "the game of attractions and repulsions between the meaning and language of literature and those of life tends now to reconstitute itself beyond the simplistic and extreme idiosyncracies of the 70s." For Forti, Eco has finally found, with his novel, "the figural solution to the infinite transparencies and stratifications of signs." The notions of recovery, return, reconstruction, restoration, recomposition, as opposed to the "loss of certainty" that Leonetti denounces, clearly emerge as central themes in both Guglielmi's and Forti's discourse. According to Forti, after the brief post-war illusion, the new democratic Power allowed literary discourse a kind of "conditional release" in newspapers, in the mass media, in schools and universities. The mistake of the neo-Avanguardia and of the experimentalisms of the 60 s and 70 s consisted in believing that they could outflank the in- 
vasive tendencies of mercantilism and "exorcize the growing pressures of industrialized society and of its advanced technologies, stylistically imitating their modes and images to the point of warping them." We now witness a process of "reconstruction" and "reconstitution" in literary language with respect to the previous "absolute or tendentially absolute divorce from the real." Examples of this restorative tendency are found in all generations: from the late Montale, to Caproni, Bertolucci ("polyphonic recomposition of the poem or verse novel"), Luzi, Sanguineti (the provocative distortion is succeeded by an "ironic, diaristic communicativity"), Maria Luisa Spaziani, Raboni, Porta ("communicability of a full sentiment"), Amelia Rosselli, and "beyond the nihilistic earthquake of the 70s," Bellezza, Cucchi, Conte, Viviani, De Angelis, Biancamaria Frabotta.

In effect, the texts of many of the younger poets cited by Forti and present at the meeting (Cucchi, Viviani, De Angelis, Frabotta), exhibit the signs of a new existentialism enacting a recovery of the self as the "true" subject of poetic discourse. This new existentialism dangerously resembles "bio-graphism," and Cucchi rightly warns against identifying "the poetic self with the biographical self" (cf. Giorgio Biancioni, "Un seminario" [A Seminar], Alfabeta no. 65, October 1984, p. 17). What is perplexing, both in Forti's text and in the poetic testimonies of the youngest (as well as of some texts by older poets), is the notion that a "reconstitution of the 'self' of the writer," and a "rebirth" of the relationship between signifier and signified (Forti, p. 7), is indeed possible. An ontology of the subject and of the word as origin and telos is implicit in this notion, which seems no less illusory than the experimental strategies, the mimesis of chaos and of schizophrenia in the discourse of the Neo-avanguardia poets. "One forgot," writes Forti, "and even today sometimes one forgets, that at the beginning (and at the end) of every form of spectacle and communication there is the word: the word thought, pronounced, and finally written by an author.... Its essence remains unchanged, even in the age of the computer and of telematics."

Gilberto Finzi's notion of the subject and of literary discourse, mediated by Borges, is complex: literature is a place for the creation of doubles, and for the representation of a self that is divided and refracted in the Other. But Finzi essentially shows himself to be in agreement with Forti: "in this word that takes on a new, truer life through writing ... the 'meaning of literature' and 
'meaning of life' can coincide once again" ("La forza di suggestione" [The Power of Suggestion], Alfabeta no. 64, September 1984 , p. 15). For Natale Tedesco as well, "the true depository . . . of the new civilization of the image is, in the last instance, still the word," and there is today a need for "new foundations": "the need for the language of the writer to make the multifariousness of today's reality comprehensible to us, thus freeing us from alienation" ("L'occhio lungo quanto memoria" [Vision as long as memory], Alfabeta nos. 62-63, July-August 1984).

No nostalgia of an ontological or restorative type, and no lamentation for the loss of the unity of knowledge and experience or the weakening of certainties emerged from the presentations of more "mature" writers and critics, like Malerba and Tabucchi. Both writers compared the situation of literary discourse to that of the new physics, so that if literature is a "symbolic representation of life," it is so inasmuch as it is an exploration of the infinite possibilities of being. Therefore it is not immune from a sense of the relative or of loss of direction (John Donne's verses, written in a period of similar weakening of certainties, come to mind: "[A] new Philosophy calls all in doubt, / . . The Sunne is lost, and th'earth, and no mans wit / Can well direct him, where to looke for it . . What Artist now dares boast that he can bring / Heaven hither, or constellate any thing?"). The ethical question that characterizes the first line was present in the critical remarks of other "mature" writers and poets, along with an impulse to rediscover a "transparent" writing, one that is less self-referential, opaque, and ambiguous, and more communicative. However, no attempt to restore ontological certainties emerged. In his last volume of poetry Porta says that he wants to "squeeze the word that has become transparent," and in his written contribution entitled "Sentimento e forma, appunti" ([Sentiment and Form, Notes], Alfabeta no. 57 , February 1984 , p. 5), he declares that he no longer believes in the validity of the "precious Heideggerian formula of language as a 'house of being,' nor in the old shortcut, by now impracticable, according to which being is language." But if the Heideggerian formula (metaphor is reality) turns out to be unusable, Porta recognizes that in order to define "that being that shatters us and silences us," one must recover the meaning of the "word sentiment, that is, use another metaphor, which denounces the non-availability of being. The meaning of literature today resides in the act of giving form to sentiment. Therefore one must begin anew with the sentiment and not with the form." "Meaning," 
then, is the direction to be given to this metaphoric route, a movement of discourse away from the metaphysical or baroque conceit and from the slidings of the signifier. It is a phenomenologicalexistential route which involves a more punctilious and attentive recognition of "sentiment." Inasmuch as it is a language of the immediate, "sentiment" makes us suspect or hope that being will actually disclose itself to us. What is involved, as Porta notes referring to Calvino's Palomar, is a "self-questioning that goes beyond all certainties."

Pontiggia, an author frequently quoted (perhaps because he is "creatively misread") as an example of the restoration of the subject and of the communicative value of literary discourse, also insists on literature as an interrogation and a metaphoric-"imaginal" journey: "A narrator who ventures into a story does not tend so much to bring himself to light (an activity that turns out to be strangely gratifying for too many people), but searches instead in an unknown land ... [through the] imaginal force of the word" (Alfabeta no. 66, November 1984). The force of these poeticcritical comments, compared to those which are merely critical, undoubtedly lies in the "imaginal" suggestion of their metaphoric discourse, which allows the reader, as the title of Pontiggia's text states, to "interrogate himself," primarily and specifically, about the meaning of words.

The text of the poet and critic Giovanni Raboni makes use of an effective metaphor in its title, "Miopi e presbiti" (The nearsighted and the far-sighted), which recalls the title of a wellknown book by the American deconstructionist critic Paul de Man, Blindness and Insight. For de Man, every vision or interpretation is partially blinded. Often it is precisely the blindness of an interpretation that involuntarily furnishes a new revelation and a new vision for another critic. Although he is somewhat distant from the deconstructionist perspective, Raboni notes that "every type of rigorous formal approach to the literary text brings with it and requires a certain near-sightedness (the near-sighted see well up close), while every definition or understanding of literature presupposes a certain far-sightedness (the far-sighted see well at a distance, they see the territory, the landscape)" (Alfabeta no. 58, March 1984, p. 7). According to Raboni, the decade which has just ended "appears as a substantially empty decade, traversed by trends and counter-trends so minutely divided that they represent ... a sort of immobile equilibrium." The 70 s, with the rigorous 
analyses of texts, the defenses of the "autonomy and the ineffability of the literary text" and the bewildering textual inventions of post-experimentalism, appear "indescribable," precisely because we no longer succeed in focussing on the overall panorama. To counteract this widespread nearsightedness among writers and critics and the threat of a complete loss of meaning, a new farsightedness developed in the $80 \mathrm{~s}$. This is positive inasmuch as it allows a "new attribution of meaning to literature. A new meaning is born out of the encounter between the new expectation for communicative clarity and the current experimentation with the residual or rediscovered or reinvented communicative possibilities of literary language."

Undeniably, it is precisely this impulse toward the "attribution of meaning," and toward a general topographic survey of the field of literary discourse, that prompted both the organization of the Palermo meeting and the participation of so many writers and critics. Raboni himself sees this movement, which I would define one of "ethical illuminism," as highly positive, and he also names prose writers, like Calvino and Pontiggia, and poets like Sereni, Caproni, Giudici and Porta, as examples of the "new attribution of meaning" in contemporary literary discourse.

Besides the "existentialist" or "ethical" ramification described above, the line arguing for a renewed engagement of literature also has a more properly political ramification with a Marxist orientation. The most representative voices of this orientation, which represents in itself a rebirth of political criticism after the post1968 ideological crisis, are those of Gian Carlo Ferretti, a perceptive critic of the neo-Avanguardia (cf. for example Il mercato delle lettere [The Market of Letters], Torino: Einaudi, 1979), and Romano Luperini, co-editor, together with Carlo Alberto Madrignani, of the new journal titled (after Dante) "L'ombra d'Argo" (The Shadow of Argo), "for a materialistic study of literature," that is, a contextualization of the literary work in the history of culture, of economics, etc. Also, the new series of Bàrberi-Squarotti and Gianluigi Beccaria's journal Sigma testifies to the revival of an interest in Marxist or generally historicist criticism, after the hegemony of structuralism, semiotics and post-structuralism/deconstruction. Deconstruction, however, never really "caught on" in Italy, except for the influence it exercised on philosophical thought, the socalled "pensiero debole" (weak ontology) of which the anthological volume edited by Gianni Vattimo and Pier Aldo Rovatti pro- 
vides an overview. Il pensiero debole (Milano: Feltrinelli, 1983) contains essays by Amoroso, Carchia, Comalli, Costa, Crespi, Dal Lago, Eco, Ferraris, Marconi, Rovatti and Vattimo.

In the first issue of Sigma, Bàrberi-Squarotti claims that literature and creativity are threatened with extinction by political power. Among the many replies to Bàrberi-Squarotti's "provocation," Gianni Vattimo's response stands out, both because it expresses a "minority" opinion, and because, with a move typical of deconstruction, it "shifts" the problem. Vattimo's claim is that literature has a "mortal" destiny. But it was the second issue of Sigma, in which Gianluigi Beccaria expressed the will for a return to the "high style" as "the reverse of show-offish audacity, grammatical arbitrariness, and experimentalisms ... and a reinsertion into a continuity, opposed to the belief in destruction and fracture" (XVI, 1983, 2-3:16), that raised the most resounding echo both at the Palermo meeting and outside of it. Many were in agreement, but many, fortunately, were in disagreement. Most significant were the refutations and disagreements on the part of poets: Luzi, Sanguineti and Zanzotto said no; the last two expressed their opinions in verse.

In responding implicitly to Arbasino's condemnation of the recovery of "the culture of the masses" because such a recovery has produced nothing but "trash," Ferretti picks up a theme already touched upon by Guglielmi. He notes that it is by now practically impossible to distinguish between "literature for consumption and of research, paraliterature and literature" ("Ricerca e consumo" [Research and consumption], Alfabeta no. 57, February 1984). The post-modern phenomenon in literature provides us with an example of "the bridging of the gap between the novel for consumption and the novel of research, through the unscrupulous and ironic use of the quote." How, then, does one place a value on literature? Ferretti's answer does not seem very original: "the true criterion for discrimination will be precisely the duration of consumption, the more or less brief or long consumability of the work (from immediate to inexhaustible)." The idea, borrowed from Habermas, of "communicative action" in the linguistic realm seems more interesting. The complexity and contradictoriness of the relationship between individual and collective discourse and forces of production allow for a transgression to occur in the form of a reconciliation (Beccaria's high style?). Literary innovation itself is no longer describable "with the known terms of repetitio 
and inventio, of consumption and research," but can emerge in "contradictory coincidences."

Romano Luperini finds fewer reasons for optimism in his analysis of the current situation of literature in Italy: "We are in a moment of opaque inertia: at a dead point, or a zero degree. There was 1963, then 1968, then the reactions to both, then the poets in love and the public poetry readings. . . . Today there is nothing. ... The multi-media empire rules ... literature ... barely survives." ("Statuto del 'letterario scritto" [The Statute of the 'Written Literary'], Alfabeta no. 60, May 1984, p. 15). Nor does the picture change, says Luperini, if one looks at the critical panorama: "First there was structuralism, then came psycho-criticism, semio-criticism, and the neo-hermeneutic mode. Today everything is silent. Every critic, curled up in his niche, nibbles on his micro-speculations." Notwithstanding this apocalyptic panorama, Luperini perceives a positive element in the function of the criticprofessor or teacher: through it "the literary formation of a people is carried on - at least for as long as there is an educational system." Bound to this critical-educative function is the need to historicize literature, to delineate general panoramas and to rediscover "the argumentative character" of criticism, its "social and civil" commitment. Literature, for its part, will have to emerge from the zero degree in which it finds itself, rediscovering History and "the roots of tradition and of the avant-garde: because it is necessary to restore museums in order to reopen a breach in their walls."

The absence of a restorative or reconstructive impulse (of history, of form, of the subject, and of the relationship between art and life, signifier and signified, etc.) characterized the contributions of the "second line." This was represented, above all, though not exclusively, by "young" critics, like Roberto Carifi and Maurizio Ferraris, by students of "foreign" literatures, like Stefano Agosti and Ferruccio Masini, and by specialists in other sectors, like Aldo Gargani, Filiberto Menna and Paolo Bertetto. The text by Paolo Bertetto (still unpublished), a cinema critic who does not fear the negative (Il piú brutto del mondo [The Ugliest in the World]), referred explicitly to post-Nietzschean thought and deconstruction: "If the question about the meaning of literature produces verbiage and revolves around a negative heart and something unpronounceable, this is not only because the general symbolic systems have come apart and, as Nietzsche wrote, 'the 
real world has become a fable' and 'random fragments' constitute the horizon of the visible, but also because it is within literature that meaning itself is lacking." Citing Mallarmé and Pessoa ("Mi renda la mia ultima magia / la statua di me in corpo vivo! / Muoia chi sono. Ma chi mi feci e fui, / anonima presenza che si bacia, / carne di astratto amore in me recluso, / sia la morte di me in cui riviva, / e quale fui, essendo nulla, io sia!"), Bertetto argued for the possibility of a "spectral" meaning of literature that "smashes the very confines of recognized symbolic systems and reaches beyond them, posing the possibility, through the flow of writing, of a thought that does not want to think, and that is semantically unrepresentable." Bertetto also challenged the manipulation of the term "post-modern" on the part of those who "with skill, but also with excessive shallowness, claim there has been a recovery of the fable and of referentiality and figurality." In light of the fundamental philosophical articulations of the 20th century, with the loss of any organic conception of the subject, the dissolution of the coordinates and of the explicit finality of history, and the fall of a centralized representational model of vision, such a recovery appears to be unlikely. "If the word does not name otherness and representation no longer constitutes itself on the basis of a homology with the represented, if this is true, then an epochal turn has taken place and the efforts to ignore it or hide it are the sign of a renunciation, comfortable perhaps, but truly miserable."

What are the consequences of this notion of a "spectral" sense of literature, and what are the spaces that it creates for writing? Bertetto refers to the Derridian conception of "closure of representation": "To close the representation signifies distancing it from the traps of the present, which pretends to abolish every difference (primarily that between reality and the symbolic). [We are dealing with] a sort of negative presentation, an ellipsis that approaches the unrepresentable and its sense, without naming it. . . To close the representation means to open the scene of writing [and] implies the affirmation of not only a specificity, but of a radical irreducibility of literature that neither narrative nor thought can replace or substitute." What we have, therefore, is a "paradoxical" model of writing, at once transitive and intransitive, projected on the world and arbitrarily autonomous, without a true object but not without objects.

An equally paradoxical notion of writing, and of the "meaning" of literature, is present in the beautiful text by Roberto Carifi 
(author of Il gesto di Callicle [Callicle's Gesture]), entitled "Elogio della debolezza" [Praise of Weakness], (Alfabeta no. 60, May 1984, p. 16), partly based on the notion of "weak ontology." The "meaning" of literature, Carifi writes, quoting Blanchot, consists in "keeping watch over the absent meaning," in "recalling the originary groundlessness of language, in the exact perception of the negative." This "weak" attitude on the part of literary discourse is what differentiates literature from "strong" discourses, both philosophical-ontological and scientific. Reacting to the accusation of nihilism or absolute relativism that is often made against "weak ontology," Carifi notes that "this weakening favors aperture, passage, constant questioning" - and at this point a surprising affinity emerges between Carifi's text and Pontiggia's cited "Interrogarsi" (To Interrogate Oneself). Carifi notes, in fact, that beyond or before the theoretical-critical debates, the actual literary, but primarily poetic, work of the last years shows that writers have been practising for some time "an ethic of weakness as the basis of their poetic thinking."

Ferruccio Masini, in a reflection on the situation of German literature ("La ricerca in Germania" [Research in Germany], Alfabeta no. 61, June 1984, p. 7), notes that the excesses of experimentalism and formalism (already stigmatized by Luperini) that characterize a large part of contemporary German literature (from Handke to Heissenbuttel to Mon), seem to produce an erasure of meaning, due to the discovery that literature does not and cannot represent life. This can make "the meaning" of literature seem like a false problem. For Masini, as for Bertetto and Carifi, what is at stake is "a different way of posing the problem of meaning in the wake of the dissolution of humanism, for which 'meaning' no longer means the humanization of discourse, the centrality of an order of values, of which man constitutes the fundamental building block. . . . Literature can have a meaning, inasmuch as it is destined to put it into play, so as to make it the non-foundation on which the being of literature itself is founded."

The dissolution of the "good sense" of literary and aesthetic discourse, in general founded on man as the subject, is a theme that recurs in the presentations of two critics of disparate orientations and interests such as Stefano Agosti and Filiberto Menna, and in the text by the philosopher Aldo Gargani. Menna reflects on the experiences of the artistic neo-Avanguardia in the $70 \mathrm{~s}$ and of the "second-hand" and "anachronistic" art of the 70s, and 
above all on their relationship with predecessors and the tradition defining it in Bloomian terms of "influence and anxiety." Menna asks what the new "intentions" can be, "when everything seems to converge on the sudden and the spontaneous, on a decentered, dislocated subjectivity" ("L'artista e la storia dell'arte" [The Artist and the History of Art], Alfabeta nos. 62-63, July-August 1984 , p. 11). The project of reconstruction or restoration of the subject, of a new mimesis and of a "systematization," is hardly a viable one. "Evidently the question cannot be posed in terms of a 'strong' project which implies the presence of a sovereign subject, a full subject, guaranteed a secure rationality in order to hold up under the attack of the real by moving along paths within well defined borders. Today, if we can still speak of the subject, we can no longer conceive of its fullness and centrality but, if anything, on provisional, precarious equilibriums, achieved from time to time (and continuously lost)." On the basis of these provisional equilibriums the artist will then pursue a form "that has, above all, a value in itself, not measured against the expectations of the consumer and the emerging demands of the market." We will find ourselves avoiding rigidity in our projects, so that the final result will not be predetermined, but will present itself as "heterodox, unforeseeable with respect to the premises of the project and to the abstract purity of the method."

In his oral presentation (woven around a collage of texts by Mallarmé) and in his written text ("Dialogo tra Mallarmé e un redattore di Alfabeta" [Dialogue between Mallarmé and an Editor of Alfabeta], Alfabeta no. 66, November 1984, p. 3-4), Stefano Agosti based his discussion of the meaning of literature on the distinction between meaning and sense. Poetry is defined, according to Mallarmé, in terms of an incessantly posed, radical interrogation of language, in which "situations of sense ... on the whole extraneous to the content which is normally conveyed by discourse, and which are defined as 'meaning' (signifiés)," are produced. In the oral presentation, the distinction between sense and meaning was enriched by a Lacanian metaphorization: discourse, as a producer of signifieds based on the semantic value emitted by semiotic-linguistic codes, is the "discourse of the Father," to which the transgressive discourse of the "Mother," that is, the multiplicity of senses produced by the literary in its work on language, is opposed. No sense is produced without the support of the signified, but the truth is not found at the level of the signified: it can be retraced only in a "demi-denial" condition, 
while the real remains that which the codes do not succeed in containing or in producing. It is precisely this absence of truth and of the real that the discourse of the Mother throws light on and "denounces."

A similar, but more politicized, metaphorization is adopted by Gargani in his splendid poetic-critical text (the only feminist text or presentation), entitled "La voce femminile" ([The Feminine Voice], Alfabeta no. 64, September 1984, p. 16). This is a text in which the ethical-political problems posed by Leonetti, and characteristic of the "first line," are interwoven with the weak/strong opposition evoked in many other presentations of the "second line," and the question of what is "specific" to literary discourse, both in its relationship to the tradition and to history, and in the dialectic of sense and meaning outlined by Agosti. According to Gargani, the "feminine voice" shows itself in the form of an interrogation: it is the voice of "difference," and is opposed to a masculine voice that tends to advance theses, construct systems, and insists on the "possession of the facts," that "possession by which one ends up being possessed." The feminine voice "discovers, beyond the facts, in the theses and systems built by men, the space for contingency, for the understanding of sense." The feminine voice (although Gargani refers specifically to Virginia Woolf and Ingeborg Bachman) does not seem to coincide only with the voices of women, but above all with a "weak" mode of thinking, according to which "the system, the axiom of a foundation, the rigid continuity that does nothing but build on a foundation that one wants carefully to protect ... and that is instead solely an originary will, are rejected." Therefore the feminine voice can belong both to men and to women: it is the voice of the "courage of sense," and of "those 'weak' persons ... . who are poets and writers." The tension of sense, "through which alone humanity detaches itself from the ... violence of the deadly word, the chill of the strategies of History," is found in the feminine voice as remembrance. "But we are not talking about a memory of deeds which took place, but rather of possibilities." The ethical nature of the feminine voice emerges "in the recall of all the signs, traces, voices that have been forgotten and ignored. ... The feminine voice is the subtext that accompanies official history conducted and fought by men bearing arms."

If one can speak of "results" or "conclusions" to draw from the meeting and from the debate on the meaning of literature 
twenty years after the conventions of the Gruppo 63 (Palermo 1963, Reggio Emilia 1964, and Palermo again in 1965), one must say that at this symposium, as in that of 1963, two principal lines emerged. In the past the lines of the past had been the "visceral" and non-ideological one of the "zero-degree," and the Marxist one endorsing the notion of a symbiotic relationship between language and ideology. But the reactions of the press and the eloquent silence of many (from Volponi to Sciascia, from Attilio Bertolucci to Zanzotto; not to speak of the women: from Amelia Rosselli to Natalia Ginzburg all, for various reasons, absent) indicate a lack of consensus and a persistant unwillingness on the part of a considerable sector of the Italian literary scene to become once again involved in public debates on the "meaning" and function of literature. Perhaps this unwillingness can be interpreted as an unspoken endorsement of the second "minority" line, and of its questioning the very question of "meaning" in relation to literature. Notwithstanding the two principal tendencies, the first "restorative" and the second "post-structuralist" and "weak," more differences and individual research concerns emerged than points of contact or a common project and/or poetics. This fact in itself can lead one to think that the second line is less of a minority one (although more "reticent") than it appears. In effect, this period of literary and esthetic research in Italy, this "fin de siècle," seems to be characterized by solitude and individual reflection, never devoid however of the Bloomian "anxiety of influence," lived and expressed in highly diverse ways. Common to all those who think or write today is, in any event, a problem evoked by Maurizio Ferraris in his Derridian pastiche of quotations ("Alcune citazioni" [A Few Quotations], Alfabeta no. 65, October 1984, p. 15-16), that already obsessed Flaubert ("I would like to write a book about nothing ..." ) and that, according to Roland Barthes, constitutes the sense of literature: "Men do not resign themselves to the fact that between the real and language there is no parallelism, and it is this refusal, as ancient perhaps as language itself, that produces, in a climate of incessant unrest, literature."

University of California at Los Angeles 